\title{
Quality of maize seeds harvested and husked at high moisture levels ${ }^{1}$
}

\author{
Valquíria de Fátima Ferreira ${ }^{2 *}$, João Almir Oliveira ${ }^{2}$, Thaís Francielle Ferreira², \\ Leandro Vilela Reis ${ }^{2}$, Vanessa de Andrade ${ }^{2}$, Jaime Costa Neto $^{2}$
}

\begin{abstract}
Harvest of maize seeds with high moisture levels has been recommended; nevertheless, after harvest, the ears undergo the process of husking and there is a need to assess the compatibility of these processes. The purpose of this study was to assess the effects of mechanical husking on the quality of maize seeds collected at high moisture levels. Dent BM 3061 hybrid maize seeds, manually collected from the ear, with moisture contents of $45 \%, 40 \%$ and $35 \%$, and a $20 / 64$ round sieve were used. The ears were mechanically husked (CWA machine, $312 \mathrm{rpm}$ ), dried in a stationary drier at $35{ }^{\circ} \mathrm{C}$ until reaching $22 \%$ moisture, followed by drying at $42{ }^{\circ} \mathrm{C}$ until reaching $12 \%$. Then, they underwent shelling, followed by a chemical treatment with Maxin ${ }^{\circledR}+\mathrm{K}$-obiol ${ }^{\circledR}+$ Actellic $^{\circledR}$. Seed quality was assessed according to the occurrence tests of mechanical damage, first count, germination, seedling emergence, emergence speed index, average emergence time, electrical conductivity, accelerated aging, cold test, and seed health test at every quarter for 9 months. The mechanical husking affects maize seed quality, depending on the degree of seed moisture at harvest and on the material studied. This hybrid's seeds can be collected with seed moisture levels at $40 \%$ with the use of mechanical husking.
\end{abstract}

Index terms: Zea mays, mechanical husking, mechanical damage, early harvest.

\section{Qualidade de sementes de milho colhidas e despalhadas com altos teores de água}

\begin{abstract}
RESUMO - A colheita de sementes de milho tem sido recomendada com elevados teores de água, no entanto, após a colheita, as espigas são submetidas à despalha, sendo necessário avaliar a compatibilidade destes processos. O objetivo foi avaliar os efeitos da despalha mecânica na qualidade de sementes de milho colhidas com elevados teores de água. Foram utilizadas sementes de milho híbrido BM 3061 dentado, peneira circular 20/64, colhidas manualmente em espigas, com teores de água de $45 \%, 40 \%$ e $35 \%$, despalha mecânica (despalhadora CWA, $312 \mathrm{rpm}$ ), secagem em secador estacionário a $35^{\circ} \mathrm{C}$ até atingirem $22 \%$ de teor de água e posterior secagem a $42{ }^{\circ} \mathrm{C}$ até $12 \%$. Procedeu-se a debulha seguida do tratamento químico com Maxin ${ }^{\circledR}+$ K-obiol $^{\circledR}+$ Actellic $^{\circledR}$. A qualidade das sementes foi avaliada pelos testes de incidência de danos mecânicos, primeira contagem, germinação, emergência de plântulas, índice de velocidade de emergência, tempo médio de emergência, condutividade elétrica, envelhecimento acelerado, teste frio e teste de sanidade, a cada três meses, durante nove meses. A despalha mecânica interfere na qualidade das sementes de milho, dependendo da umidade das mesmas na colheita e do material estudado. Sementes desse híbrido podem ser colhidas com teores de água de $40 \%$ com utilização da despalha mecânica.
\end{abstract}

Termos para indexação: Zea mays, despalha mecânica, danos mecânicos, colheita antecipada.

\section{Introduction}

The maize (Zea mays L.) is a plant of great importance to Brazil. In the 2012 harvest, about 73 million tons of grain were produced, with growing area of 15.4 million hectares and an average yield of 4.4 t.ha ${ }^{-1}$, which represents an increase of $18 \%$ compared to previous crop (CONAB, 2012). To increasingly reach larger productions, it is extremely important to use good quality seed, and in order to do so, the monitoring of seed moisture content, maximum dry matter accumulation, and appearance of black layer are important aspects. The quality of maize seeds can be guaranteed by early harvest, due to its less exposure to adverse environmental conditions, insect attack, fungus and exposure to a variety of climatic factors, such as humidity and temperature, in addition, it provides better utilization of the production and processing

${ }^{1}$ Submitted on 09/10/2012. Accepted for publication on 04/03/2013.

${ }^{2}$ Departamento de Agricultura/Fitotecnia, UFLA, Caixa postal 3037, 37200-000 - Lavras, MG, Brasil.

*Corresponding author $<$ ffval@yahoo.com.br $>$ 
infrastructure, even if the harvesting of immature seeds occur (Vasconcelos et al., 2002).

An option for early harvest is harvesting seeds from the ear, without removing the peel and cob. This will extend the harvest period, as well as reduce the risk of seeds being contaminated by diseases of late season. Oliveira et al. (1997) have reported producers' increasing adoption of harvesting on maize ear, to obtain better quality seed, especially for simple and triplecross hybrids. The harvesting of the maize seed from the ear was carried out for many years with moisture content a little lower $35 \%$, as soon as they reached physiological maturity, followed by artificial drying. However, studies have shown that the maximum values of germination and vigor can occur when seeds have high moisture content, even before they have reached physiological maturity. Ajayi and Fakorede (2000) have also found that maize seeds harvested before full maturity, regardless of dry weight, germinate faster than those harvested at full maturity.

However, seeds harvested with high moisture content are more susceptible to mechanical damage caused mainly by machinery during harvest and husking. Oliveira et al. (2005) have stated that the mechanical damage caused by the rotation of threshing cylinder and moisture content of maize seeds at harvest may affect the germination and vigor. For Marchi et al. (2006), the progressive increase of the mechanical damage of seeds contributes to the decrease of their physiological potential and for the increased occurrence of fungi on them. Each mechanical damage affecting the seed, however small, is cumulative and an integral part of the seed damage (Menezes et al., 2002), and may reduce seed quality.

Another factor causing damage to seeds is drying. Among the post-harvest processes, artificial drying is the most relevant when dealing with maize seed harvest from ears with high moisture content. Despite its advantages, artificial drying has been causing damage to seeds, with significant reductions in their physiological quality (Roveri José et al., 2005). According to these authors the removal of water from the seeds may cause chemical, physical and physiological changes, which makes the drying process a critical step in the production of seeds. Therefore, the initial drying of maize seeds harvested with high moisture contents is recommended to be initially performed at a lower temperature, $35^{\circ} \mathrm{C}$, since it appears to simulate the processes which normally occur to the plant, allowing the mechanisms of tolerance to desiccation to become active or to be imposed on seeds (Rosa et al., 2000). During the natural drying of seeds in the field, they lose water gradually, allowing the development of mechanisms of tolerance, preparing them to withstand the consequences of dehydration (Marcos-Filho, 2005).
The production process occurs with the preservation of seed quality during storage, which is a fundamental aspect to be considered.

Thus, the objective of this research was to investigate the effects of mechanical husking on the seed quality of maize harvested with high moisture content, before and after storage.

\section{Material and Methods}

In this research, BM 3061 hybrid maize seeds were used, classified as dented, produced by Biomatrix in the city of Paracatú - MG, Brazil. The city is located in the northwest of the state of Minas Gerais, with geodetic coordinates $17^{\circ}$ $13^{\prime} 19^{\prime \prime} \mathrm{S}$ of latitude, $46^{\circ} 52^{\prime} 30^{\prime \prime} \mathrm{W}$ of longitude, and with altitude of 1008 meters.

A completely randomized design in a factorial $3 \times 2 \times$ 4 were used, which factors were moisture content of seeds at harvest (45, 40 and 35\%), seed treatment (treated and untreated), and periods of storage ( $0,3,6,9$ months), with four replicates per treatment.

Ear harvesting was performed manually when the seeds had 45,40 , and $35 \%$ of moisture content, and the multi-grain unit device was used to determine such moisture content. After harvest, the husking of ears was conducted with a CWA, 312 rpm mechanical corn husker. Then, the ears were dried in a stationary dryer at $35{ }^{\circ} \mathrm{C}$ until seeds reached $22 \%$ of moisture content, followed by drying at $42{ }^{\circ} \mathrm{C}$ until they reached $12 \%$. After drying, the seeds were mechanically shelled and treated with Maxim ${ }^{\circledR}+$ K-obiol $^{\circledR}+$ Acctelic $^{\circledR}$, which consisted of $22 \mathrm{~L}$ of Maxim XL, $700 \mathrm{~mL}$ of K-Obiol, $700 \mathrm{~mL}$ of Actellic, $4 \mathrm{~L}$ of dye, 156.6 L of water (in 16 tons of seed).

In the Central Seed Laboratory of the Department of Agriculture at the Federal University of Lavras, seeds were submitted to manual sieve classification, and the seeds retained by a 20/64 round sieve were used for this study.

The seeds were subjected to physiological quality tests carried out after harvest and at every three months during nine months of storage (controlled temperature with an average of $25{ }^{\circ} \mathrm{C}$ and relative humidity of $62 \%$ ), as described below:

Occurrence of mechanical damage: it was assessed after the homogenization of samples, by using four subsamples of 100 seeds (400 seeds/treatment). The seeds were immersed in an amaranth solution ${ }^{\circledR}$ at $0.1 \%$, for two minutes, and then were washed in tap water. The seeds were categorized into four levels of damage, and were graded from zero to three, in accordance with the methodology of Oliveira et al. (1998), where 0 (zero) score represents seeds that visually have no damage; 1 represents seeds with surface damage, away from the embryonic axis and / or near the point of cob insertion, if 
in area below $10 \%$ of the seed; 2 represents seeds showing severe damage anywhere except in the embryonic axis, if in area ranging from $10-40 \%$ of the seed; 3 represents seeds presenting intense damage in the endosperm, with an area greater than $40 \%$ and / or directly associated with the embryo.

Germination: four subsamples with 50 seeds were sown in towel roll paper, moistened with an amount of water equivalent to 2.5 times the weight of the dry substrate, and were kept in an incubator at $25^{\circ} \mathrm{C}$. The first count was in the fourth day and the final count on the seventh day after sowing, and the percentage of normal seedlings was determined (Brasil, 2009).

Accelerated aging: the seeds were placed on wire screen in plastic gerbox, so as to cover the entire surface of the screen without overlapping seeds with $40 \mathrm{~mL}$ of distilled water on the bottom. These boxes were capped and kept in an incubator at $42{ }^{\circ} \mathrm{C}$ for 96 hours (Marcos -Filho, 1999). Then, the germination test with four subsamples with 50 seeds was performed (Brasil, 2009). The assessment was made seven days after sowing. The results were expressed as mean percentage of normal seedlings per treatment (Torres, 2005).

Seedling emergence: the seeds were sown in plastic boxes in soil:sand substrate in the 1:3 ratio and field capacity set to $60 \%$ at $25{ }^{\circ} \mathrm{C}$ in a plant growth chamber and 12-hour photoperiod. There were four subsamples with 50 seeds per treatment and the results were expressed in percentage of normal seedlings at 14 days. The speed of emergence index was performed by daily recording the emergence of seedlings, determined with the formula proposed by Maguire (1962) and mean emergence time (Labouriau, 1983).

Soilless cold test: four subsamples with 50 seeds sown in towel roll paper, moistened with water, three times the weight of the substrate. The rolls were stored in sealed plastic bags, and later were subjected to temperature of $10{ }^{\circ} \mathrm{C}$ for seven days, followed by growth of seedlings in the germination chamber at $25^{\circ} \mathrm{C}$ for four days, and then the number of normal seedlings was determined (Dias and Barros, 1995).

Electrical conductivity: four subsamples with 50 seeds for each treatment were weighed (to the nearest $0.01 \mathrm{~g}$ ) and washed in tap water for two minutes to remove the residue from the chemical treatment; the untreated seeds also went through the washing process. After that, they were placed in plastic cups containing $75 \mathrm{~mL}$ of deionized water, and were kept in an incubator set at $20^{\circ} \mathrm{C}$ for 24 hours. After this period, the solutions (with seeds submerged) were slightly agitated and the conductivity was measured in Digimed ${ }^{\circledR}$ CD-20, and the results expressed in $\mu \mathrm{S} . \mathrm{cm}^{-1} \cdot \mathrm{g}^{-1}$ of seed, according to the methodology described by Vieira (1994).

Seed health: the modified method of filter paper with freezing was used (Machado, 1988), when 200 seeds distributed in eight subsamples of 25 seeds were analyzed.

Data were subjected to analysis of variance with the Sisvar ${ }^{\circledR}$ software at $5 \%$ probability by $\mathrm{F}$ test (Ferreira, 2011). The means were compared using the Tukey test at $5 \%$ or polynomial regression analysis was performed. No statistical analysis of moisture content data was made.

\section{Results and Discussion}

The results of the analysis of variance showed that there were significant effects on the isolated factors, moisture content at harvest and storage period for the parameters of germination, speed of emergence index and mean emergence time. The seedling emergence test was not significant in any of the factors studied. The interaction of the factors moisture content at harvest and storage period was significant for the parameters first count, electrical conductivity, and occurrence of the fungus Penicillium sp., for which there was also an interaction between moisture content at harvest and seed treatment $(\mathrm{U} \times \mathrm{T})$ and seed treatment and storage period ( $\mathrm{T} \times \mathrm{E}$ ). For the parameters accelerated aging, cold test and occurrence of Fusarium sp. and Aspergillus sp., it was observed a triple interaction of factors moisture content at harvest, seed treatment and storage period ( $\mathrm{U} \times \mathrm{T} \times \mathrm{E})$.

With regard to the mechanical damages, it was observed that the hybrid had higher resistance to serious damage, with minor damage occurring predominantly (Note 1) (Figure 1). It was also noted that the higher the moisture content at harvest, the higher the occurrence of damage considered to be severe (Note 3). The occurrence of severe damage to seeds harvested at 35 and $40 \%$ moisture content was practically the same. This high occurrence of mechanical damage was caused mainly on the steps of husking and threshing, since seeds with high moisture content are more susceptible to mechanical damage. This result was also confirmed by Andrade et al. (1999) who found that in bean seeds, moisture content and mechanization in harvesting are important factors that determine how severe mechanical damage is to seeds.

According to the germination, speed of emergence index (SEI) and mean emergence time (MET), Table 1, for seeds harvested with $45 \%$ moisture content were inferior to those harvested at 40 and $35 \%$ moisture content. For seeds harvested with $40 \%$ of moisture content their quality was equal or superior to those harvested at $35 \%$. This fact can be explained by the higher occurrence of mechanical damage to seeds harvested at higher moisture contents, which resulted in the loss of seed quality. 


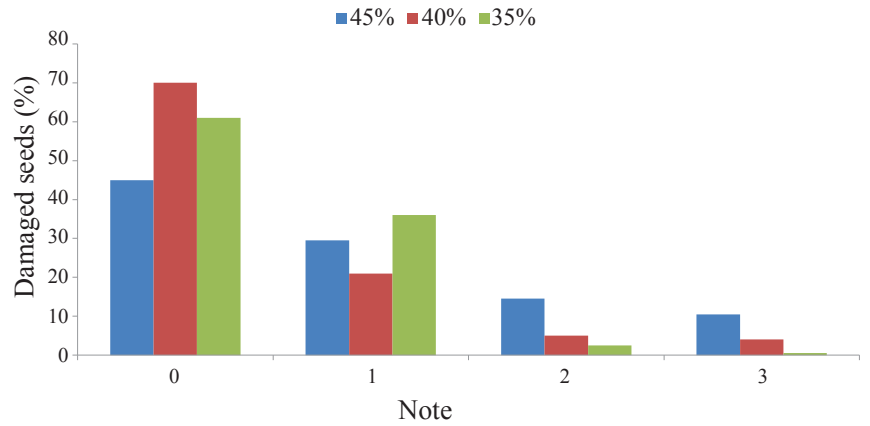

Figure 1. Occurrence of mechanical damage on dent BM 3061 hybrid maize seeds harvested at different moisture contents and classified into scores $0,1,2$ and 3 .

Table 1. Mean values of germination (G), speed of emergence index (SEI) and mean emergence time (MET) of BM 3061 hybrid maize seeds, harvested at different moisture contents.

\begin{tabular}{cccc}
\hline Moisture Content & G (\%) & SEI $(\%)$ & MET $(\%)$ \\
\hline $45 \%$ & $96 \mathrm{~b}$ & $11 \mathrm{~b}$ & $6 \mathrm{~b}$ \\
$40 \%$ & $99 \mathrm{a}$ & $12 \mathrm{a}$ & $3 \mathrm{a}$ \\
$35 \%$ & $98 \mathrm{ab}$ & $11 \mathrm{~b}$ & $4 \mathrm{ab}$ \\
\hline $\mathrm{CV}(\%)$ & 2.43 & 3.87 & 3.85 \\
\hline
\end{tabular}

Means followed by the same letters in the column do not differ by Tukey test at $5 \%$ probability.

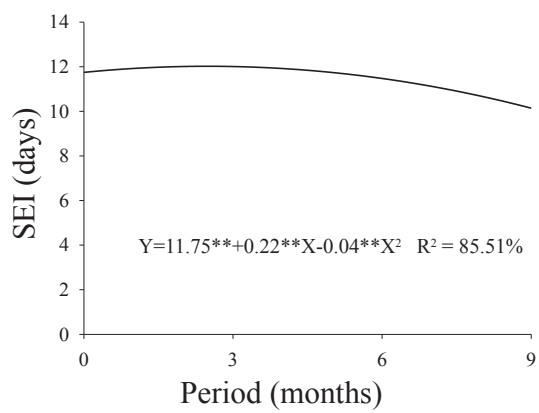

The storage period negatively affected seed germination, regardless of moisture content and seed treatment. Such decreased germinability is related to the occurrence of mechanical damage occurring in the husking process, especially the latent damage that arise during storage, which led to further deterioration of seeds.

The SEI and MET tests showed that seed vigor was reduced with storage (Figure 2); similar results were found by Souza et al. (2009) with sorghum seeds. According to these authors, both decreased germination and vigor, as seeds are harvested with higher moisture content, may be due to two factors. The first factor is deterioration, which is closely associated with the moisture content of seeds, where increased moisture content can cause an acceleration of deterioration with decreased speed of germination, growth and development of seedlings (Delouche, 2002). The second factor is the degree of mechanical injuries that can increase with increased seed moisture, which has been confirmed by Oliveira et al. (1997) when studying mechanical damage in maize seeds. Araújo et al. (2002) stated that the storage period of agricultural products damaged by impact is an important factor, considering that the damage suffered by them will worsen as time goes by, affecting the storage potential of the product.

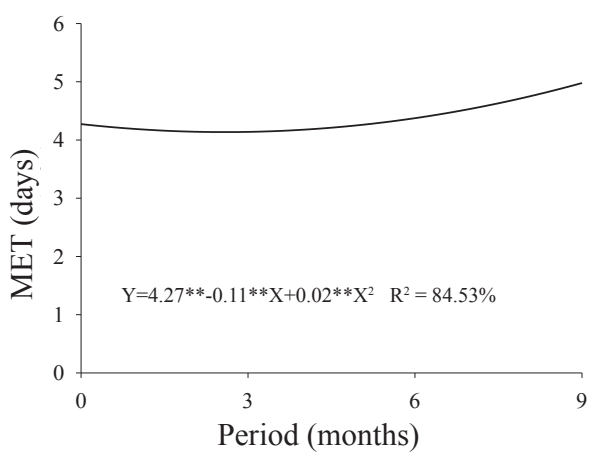

Figure 2. Regression curves of results for speed of emergence index (SEI) and mean emergence time (MET) of BM 3061 hybrid maize seeds, harvested at different moisture contents, throughout storage.

There was significant interaction between moisture content and storage period for the tests of first count and electrical conductivity (Figure 3). In the first count test, the germination of seeds harvested at $45 \%$ moisture content was lower when compared to seeds harvested at 40 and $35 \%$, and the germination of seeds harvested at $40 \%$ moisture content was higher than the other throughout the storage period. Increased moisture content produced higher occurrence of damage to seeds, which probably accelerated deterioration, thereby reducing the biosynthesis mechanisms and the production of energy (Delouche, 2002). The reduction in germination of seeds harvested with $45 \%$ moisture content can also be associated with higher occurrence of Aspergillus spp., since, according to Menezes et al. (2008), this fungus in the seeds can negatively affect germination. Seeds harvested with higher moisture content had greater occurrence of damage and thus showed higher electrical conductivity due to the disruption of cell membranes, which can also be justified by any damage caused by drying. Maybe seeds harvested with high moisture contents had not yet developed mechanisms of 
desiccation tolerance, because with advancing stages of maturity, the development and structural organization of cell membranes occur, which explains the decrease in electrical conductivity with reduced moisture content of seeds (Faria et al., 2004).

According to the results of the accelerated aging test (Figure 4), a more rapid reduction of seed vigor was noted for untreated seeds, compared to treated seeds throughout

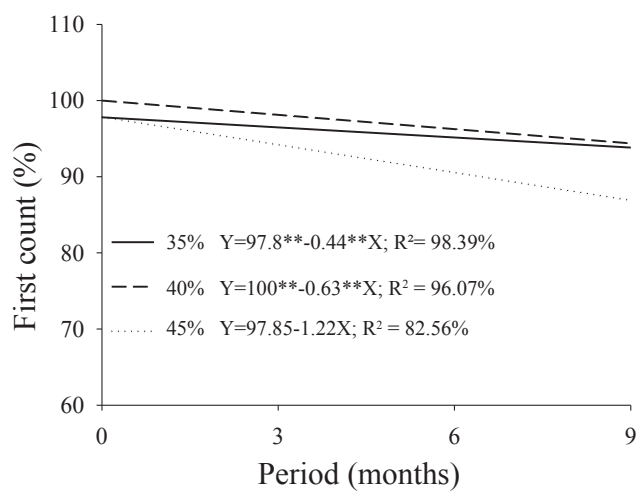

the storage period. Seed vigor of seeds harvested with 40 and $45 \%$ moisture content was similar throughout the storage period, whereas for seeds harvested with $35 \%$ moisture content, seed vigor reduced sharply in the same period. Silva and Silva (2000) have found that the accelerated aging conditions favor the development of some microorganisms, thus reducing their potential.

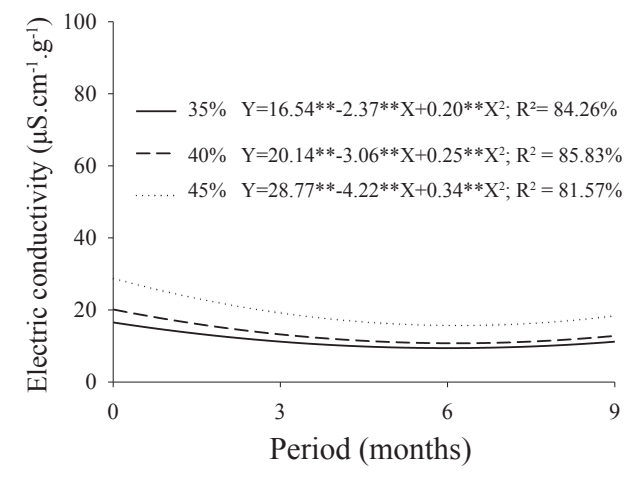

Figure 3. Regression curves of mean results for first count and electric conductivity of BM 3061 hybrid maize seeds, harvested at different moisture contents, during storage.

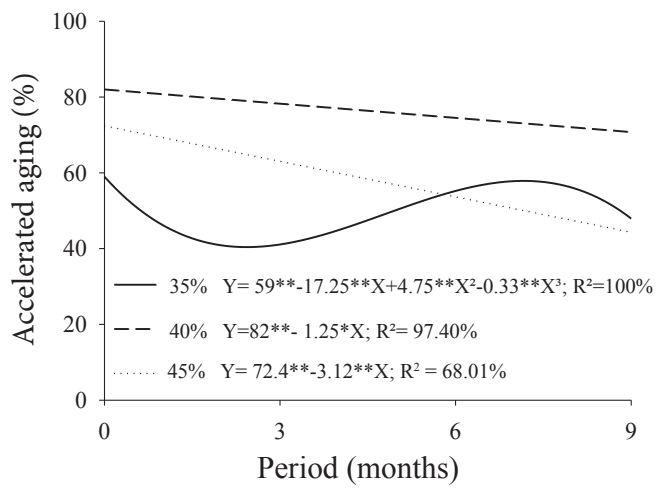

NT

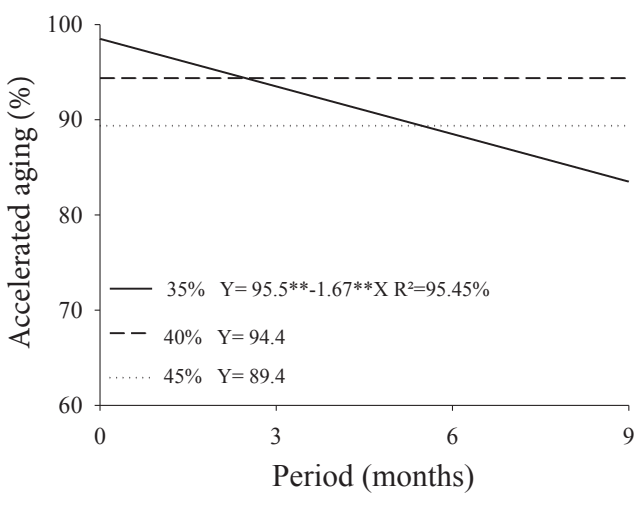

$\mathrm{T}$

Figure 4. Regression curves of mean results for germination after the accelerated aging of BM 3061 hybrid maize seeds, harvested at different moisture contents, whether untreated (NT) or treated (T), during storage.

Overall, untreated seeds resisted to the stress of the cold test better than treated seeds, throughout the storage period (Figure 5). Untreated seeds, harvested at 35\% moisture content, had higher quality changes, whereas for the treated seeds, the highest quality changes occurred for those harvested with 45\% moisture content. Bewley and Black (1994) have explained that in addition to easily losing germination and vigor during storage, seeds with mechanical damage become more vulnerable to the effects of chemical treatment.

According to Faria et al. (2002), maize seed can be harvested from LL-3 (milk line 3) with moisture contents ranging from 41 to $50 \%$ depending on the hybrid under study. However, husking was performed manually, which consequently did not cause mechanical damage. In this research, the limitation of the harvesting of maize seeds with high moisture content was determined by the occurrence of mechanical damage during the process of husking.

Regarding the sanitary quality of seeds, seed treatment was effective in controlling Fusarium moniliforme (Figure 6). During storage, there was a reduction in the occurrence of such pathogen, because it is a field fungus, and thus, it loses its pathogenicity during storage, which was also observed 
by Martins-Filho et al. (2001). These authors have noted that after the storage of soybean there was decreased occurrence of fungi, which can mainly be associated with loss of viability of the existing inoculum as surface contaminant in the form of spores. Seed moisture content at harvest was also significant for the occurrence of Fusarium sp. during this period. Higher occurrence of the fungus was observed on seeds harvested with higher moisture content, a result

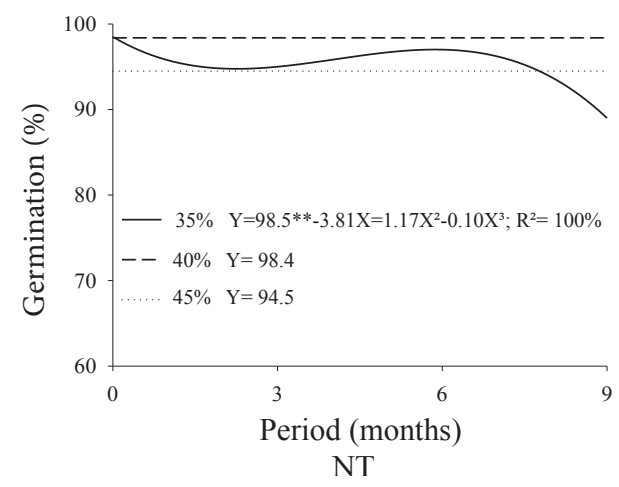

that is contrary to that of the literature, where higher levels of the fungus are found in seeds that were kept longer in the field, exposed to harsh weather conditions and to the attack of microorganisms, and thus harvested with lower moisture content (Deshpande and Kulkarni, 1991). Probably the highest rate of mechanical damage to seeds harvested at $45 \%$ moisture content facilitated the entry of the pathogen, thus increasing the occurrence of the fungus.

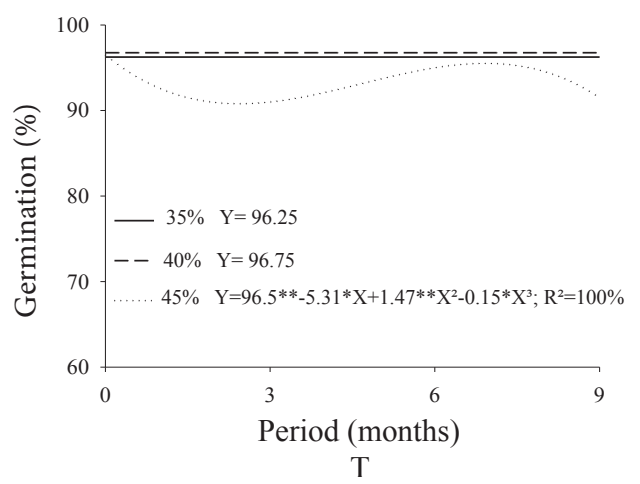

Figure 5. Regression curves of mean results for vigor by cold test (TF) of BM 3061 hybrid maize seeds, harvested at different moisture contents, whether untreated (NT) or treated (T), throughout storage.
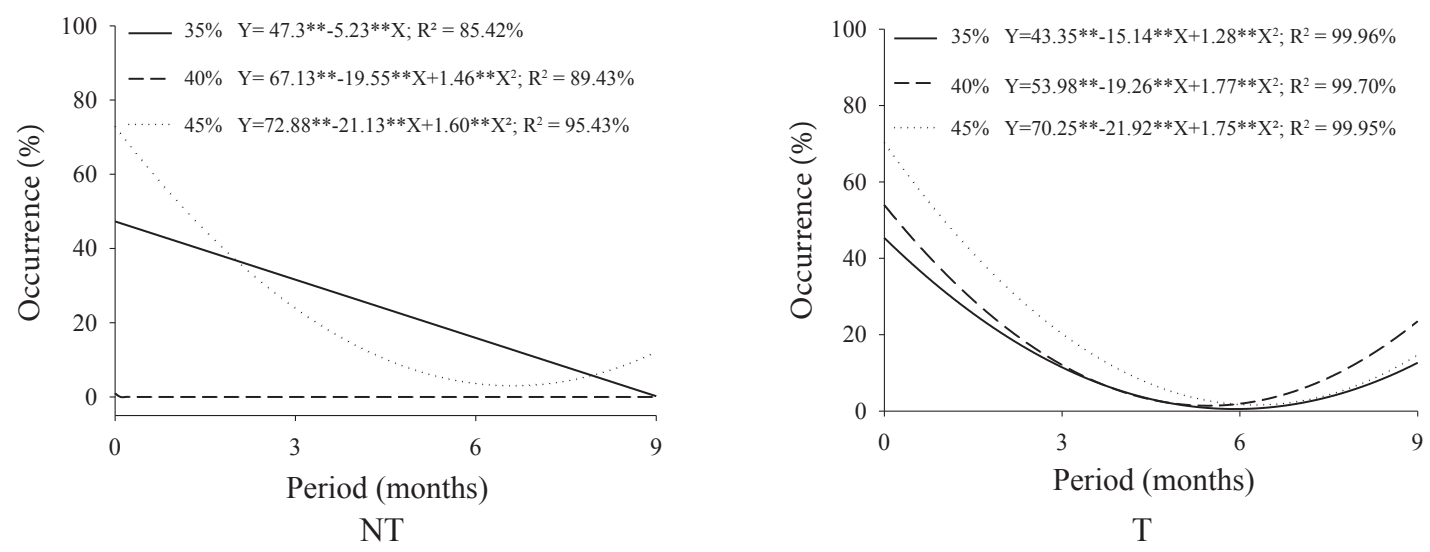

Figure 6. Regression curves of mean occurrences of Fusarium moniliforme in BM 3061 hybrid maize seeds, harvested at different moisture contents, whether untreated (NT) or treated (T), throughout storage.

Seed treatment was effective in reducing the occurrence of Penicillium sp. during storage (Figure 7 A). Regarding the significant interaction of the factors moisture content of seeds at harvest and storage period (Figure $7 \mathrm{~B}$ ), there was reduction in the occurrence of this fungus in seeds harvested at $45 \%$ moisture content over the entire study period. However, in seeds harvested with $40 \%$ moisture content, there was a trend towards increased occurrence of the fungus. As for seeds harvested at $35 \%$ moisture content, the occurrence was lower from the sixth month of storage on.
In untreated seeds, the moisture content did not affect the occurrence of the Penicillium sp. For treated seeds, its occurrence was greater in seeds harvested at $45 \%$ moisture content, probably because of their greater susceptibility to mechanical damage, which may have favored the action of this fungus. No difference was found for the occurrence of this fungus in seeds harvested at 35 and $40 \%$ moisture content.

It was observed that the occurrence of Aspergillus sp. provided no major variations among seeds harvested at different moisture contents (Figure 8), however, the highest 
occurrence of this fungus was observed in seeds harvested at $45 \%$ moisture content, and that seed treatment has reduced the occurrence of this fungus, keeping it at lower levels during storage. However, the gradual increase of mechanical damage to seeds, as moisture content increased at harvest, has contributed to the reduction of seed physiological potential and to the increased occurrence of fungi. Similar results were found by Marchi et al. (2006) who have studied the relationship among mechanical damage, chemical treatment and occurrence of pathogens in maize seed.
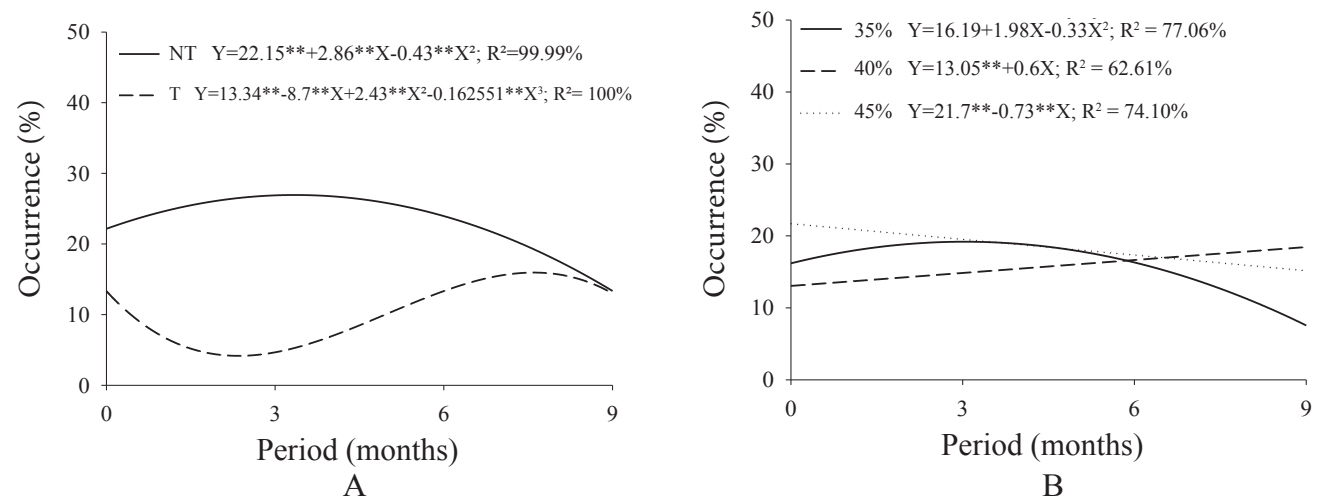

B

Figure 7. Regression curves of mean occurrences of Penicillium sp. in BM 3061 hybrid maize seeds for the interaction of factors storage period and seed treatment (A) and storage period and moisture content at harvest (B).

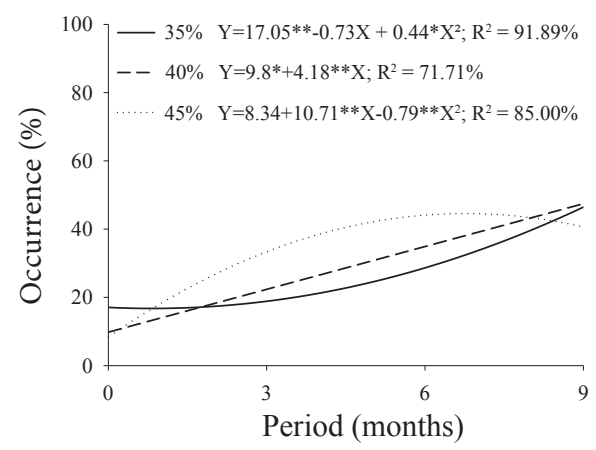

A

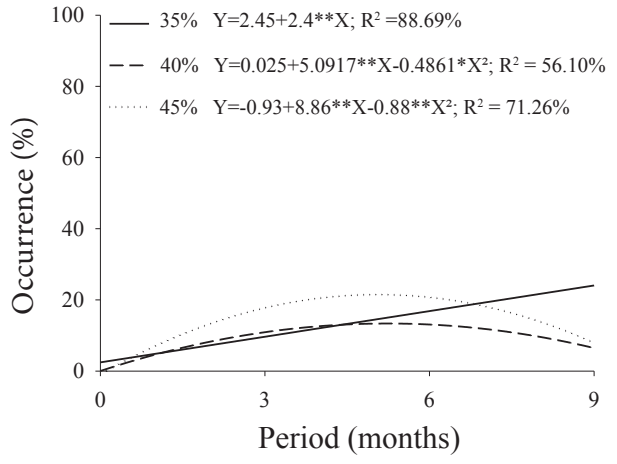

$\mathrm{B}$

Figure 8. Regression curves of mean occurrences of Aspergillus sp. in BM 3061 hybrid maize seeds for the interaction of factors: storage period and moisture content at harvest for untreated seeds (A) and treated seeds (B).

\section{Conclusions}

The husking process can affect the quality of maize seeds, depending on their moisture content at time of harvest.

The harvesting of Dent 3061 hybrid maize seeds, of 20/64 round sieve, can be made in advance and when they reach moisture contents of $40 \%$, by mechanical husking.

The gradual increase of mechanical damage to seeds, as moisture content increased at harvest, has contributed to the reduction of seed physiological potential and to the increased occurrence of fungi during storage.

\section{References}

AJAYI, S.A.; FAKOREDE, M.A.B. Physiological maturity effectes on seed quality, seedling vigour and mature plant characteristics of maize in a tropical environment. Seed Science and Technology, v.28, p.301-319, 2000. http:// www.cabdirect.org/abstracts/20026788467.html

ANDRADE, E.T.; CORRÊA, P.C.; ALVARENGA, E.M. Avaliação de dano mecânico em sementes de feijão por meio de condutividade elétrica. Revista Brasileira de Engenharia Agrícola e Ambiental, v.3, n.1, p.54-60, 1999 http://www.agriambi.com.br/revista/v3n1/054.pdf

ARAUJO, E.F.; GALVAO, J.C.C.; MIRANDA, G.V.;ARAUJO, R.F. Qualidade fisiológica de sementes de milho-doce submetidas à debulha, com diferentes graus de umidade. Revista Brasileira de Milho e Sorgo, v.1, n.2, p.101-110, 2002. http://rbms.cnpms.embrapa.br/index.php/ojs/article/viewArticle/28

BEWLEY, J.D.; BLACK, M. Seed physiology of development and germination. 2nd ed. New York: Plenum Press, 1994. 445p. 
BRASIL. Ministério da Agricultura, Pecuária e Abastecimento. Regras para análise de sementes. Ministério da Agricultura, Pecuária e Abastecimento. Secretaria de Defesa Agropecuária. Brasília: MAPA/ACS, 2009. 395p. http:// www.bs.cca.ufsc.br/publicacoes/regras\%20analise\%20sementes.pdf

COMPANHIA NACIONAL DE ABASTECIMENTO. Levantamento de grãos: Disponível: http://www.conab.gov.br/olalacms/uploads/ arquivos/12_06_12_16_15_32_boletim_portugues_junho_2012.pdf. Accessed on: Jun. $28^{\text {th }} 2012$.

DELOUCHE, J.C. Germinação, deterioração e vigor da semente. Seed News, n.6, p.24-31, 2002.

DESHPANDE, V.K.; KULKARNI, G.N. Effect of time of haversting on seed quality attributes in maize (Zea mays). Mysore Journal of Agricultural Science, v.25, n.2, p.162-164, 1991.

DIAS, M.C.L.L.; BARROS, A.S.R. Avaliação da qualidade de sementes de milho. Londrina: IAPAR, 1995. 43p.

FARIA, M.A.V.R.; VON PINHO, R.G.; VON PINHO, E.V.R.; GUIMARÃES, R.M.; FREITAS, F.E.O. Germinabilidade e tolerância à dessecação em sementes de milho colhidas em diferentes estádios de maturação. Revista Brasileira de Milho e Sorgo, v.3, n.2, p.276-289, 2004. http://rbms.cnpms. embrapa.br/index.php/ojs/article/view/108/141

FARIA, M.A.V.R.; VON PINHO, R.G.; VON PINHO, E.V.R.; GUIMARÃES, R.M.; FREITAS, F.E.O. Qualidade fisiológica de sementes de milho colhidas em diferentes estádios de "linha de leite". Revista Brasileira de Milho e Sorgo, v.1, n.1, p.93-104, 2002. http://rbms.cnpms.embrapa.br/index.php/ ojs/article/viewArticle/14

FERREIRA, D.F. Sisvar: a computer statistical analysis system. Ciência e Agrotecnologia, v.35, n.6, p.1039-1042, 2011. http://www.dex.ufla.br/ danielff/ softwares.htm

LABOURIAU, L.G. A germinação das sementes. Washington: Secretaria geral da Organização dos Estados Americanos, 1983. 174p.

MACHADO, J.C. Patologia de sementes: fundamentos e aplicações. Brasília: Ministério da Educação, 1988. 107p.

MAGUIRE, J.D. Speed of germination and in selection and evaluation for seedling emergence and vigor. Crop Science, v.2, n.2, p.176-177, 1962. http:// scholar.google.com.br/scholar?q=speed + of + germination + and + in + selection+and+evaluation+for+seedling+emergence+and+vigor\&hl=ptbr\&as_sd$\mathrm{t}=0$ \&as_vis $=1 \&$ oi $=$ scholart\&sa $=\mathrm{x} \&$ ei $=$ pgjtuogs $14 \mathrm{~g} 09$ qty 4 idaba\&sqi $=2 \&$ ve$\mathrm{d}=0$ cbwqgqmwaa

MARCHI, J.L.; MENTEN, J.O.M.; MORAES, M.H.D.; CICERO, S.M. Relação entre danos mecânicos, tratamento fungicida e incidência de patógenos em sementes de milho. Revista Brasileira de Milho e Sorgo, v.5, n.3, p.351358, 2006. http://rbms.cnpms.embrapa.br/index.php/ojs/article/viewarticle/197

MARCOS- FILHO, J. Fisiologia de sementes de plantas cultivadas. Piracicaba: FEALQ, 2005. 495p.

MARCOS-FILHO, J. Teste de envelhecimento acelerado. In: KRZYZANOWSKI, F.; VIEIRA, R.D.; FRANÇA-NETO, J.B. (Ed.). Vigor de sementes: conceitos e testes. Londrina: ABRATES, 1999. cap.3, p.1-24.

MARTINS FILHO, S.; LOPES, J.C.; RANGEL, O.J.P.; TAGLIAFERRE C. Avaliação da qualidade fisiológica de sementes de soja armazenadas em condições de ambiente natural em Alegre-ES. Revista Brasileira de Sementes, v.23, n.2, p.201-208, 2001. http://www.abrates.org.br/revista/artigos/2001/ v23n2/artigo28.pdf
MENEZES, V.O.; PEDROSO, D.C.; MUNIZ, M.F.B.; BELLÉ, R.; BLUME. E.; GARCIA, D.C. Envelhecimento acelerado em sementes de Zinnia elegans Jacq. colhidas em diferentes épocas. Revista Brasileira de Sementes, v.30, n.3, p.39-47, 2008. http://www.scielo.br/pdf/rbs/v30n3/06.pdf

MENEZES, N.L.; LERSCH-JUNIOR, I.; STORCK, L. Qualidade fisiológica da sementes de milho após o beneficiamento. Revista Brasileira de Sementes, v.24, n.1, p.97-102, 2002. http://www.scielo.br/scielo.php?pid=S010131222002000100014\&script=sci_arttext

OLIVEIRA, M.E.C.; ALMEIDA, F.A.C.; OLIVEIRA, F.M.M.; BARROS NETO, J.J.S.; GOUVEIA, J.P.G. Danificações em sementes de milho decorrentes da debulha e teor de umidade na colheita. Revista de Biologia e Ciências da Terra, v.5, n.2, 2005. http://eduep.uepb.edu.br/rbct/sumarios/ pdf/danosmecanicos.pdf

OLIVEIRA, J.A.; CARVALHO, M.G.G.V.; CARVALHO, M.L.M; SILVA, E.A.A. Utilização de corantes na verificação de incidência de danos mecânicos em sementes de milho. Revista Brasileira de Sementes, v.20, n.2, p.125-128, 1998. http://www.abrates.org.br/revista/artigos/1998/v20n2/artigo21.pdf

OLIVEIRA, J.A.; CARVALHO, M.L.M.; VIEIRA, M.G.G.C.; VON PINHO, E.V.R. Efeito do método de colheita na qualidade física, fisiológica e sanitária de sementes de milho. Revista Brasileira de Sementes, Brasília, v.19, n.2, p.201207, 1997. http://www.abrates.org.br/revista/artigos/1997/v19n2/artigo10.pdf

ROSA, S.D.V.F.; VON PINHO, E.V.R.; VIEIRA, M.G.G.C.; SANTOS, C.D.; VEIGA, R.D. Qualidade fisiológica e atividade enzimática em sementes de milho submetidas a secagem artificial. Revista Brasileira de Sementes, v.21, n.1, p.177184, 2000. http://www.abrates.org.br/revista/artigos/2000/v22n1/artigo24.pdf

ROVERI JOSÉ, S.C.B.; VON PINHO, R.G.; RAMALHO, M.A.P.; SILVA FILHO, J.L. Características físicas do pericarpo de sementes de milho associadas com a tolerância à alta temperatura de secagem. Revista Brasileira de Sementes, v.27, n.1, p.125-131, 2005. http://www.scielo.br/scielo. php?pid=S0101-31222005000100015\&script $=$ sci_abstract\&tlng=pt

SILVA, M.A.D.; SILVA, W.R. Comportamento de fungos e de sementes de feijoeiro durante o teste de envelhecimento artificial. Pesquisa Agropecuária Brasileira, v.35, n3, p.599-608, 2000.http://www.scielo.br/pdf/pab/v35n3/v35n3a16.pdf

SOUZA, G.F.M. V.; SANTOS, C.M.; SANTANA, D.G; SÁ JÚNIOR, A. Armazenamento de sementes de sorgo submetidas a diferentes graus de umidade de colheita. Semina: Ciências Agrárias, v.30, n.4, p.745-752, out./dez. 2009. http://www.uel.br/revistas/uel/index.php/semagrarias/article/view/4069/3377

TORRES, S.B. Envelhecimento acelerado em sementes de pimenta-malagueta (Capsicum frutescens L.). Revista Ciência Agronômica, v.36, n.1, p.98-104, 2005. http://redalyc.uaemex.mx/redalyc/pdf/1953/195317441012.pdf

VASCONCELOS, R.C.; VON PINHO, R.G.; REIS, R.P.; LOGATO, E.S. Tecnologias aplicadas na cultura do milho em Lavras - MG na safra 1998/1999. Ciência Agrotécnica, v.26, n.1, p.117-127, 2002. http://www.editora.ufla.br/ site/_adm/upload/revista/26-1-2002_14.pdf

VIEIRA, R.D. Teste de condutividade elétrica. In: VIEIRA, R.D.; CARVALHO, N.M. (Ed). Testes de vigor em sementes. Jaboticabal: FUNEP, 1994. p.103-132. 